\title{
Emergency responses to COVID-19 in the hospital outpatient-emergency department under diversified decision scenarios: A case study in Wuhan, China
}

Yingying Peng ( $\sim$ pengyingying1020@163.com )

Huazhong University of Science and Technology

Jiang Li

Wuhan Union Hospital

Suyun Li

Wuhan Union Hospital

Xianglin Li

Huazhong University of Science and Technology Tongji Medical College

Erping Jia

Huazhong University of Science and Technology Tongji Medical College

Liming Xiong

Wuhan Union Hospital

Juyang Xiong

Huazhong University of Science and Technology Tongji Medical College

Keywords:

Posted Date: May 20th, 2021

DOl: https://doi.org/10.21203/rs.3.rs-517099/v1

License: (9) (i) This work is licensed under a Creative Commons Attribution 4.0 International License.

Read Full License 


\section{Abstract}

The authors have requested that this preprint be removed from Research Square. 